\title{
EVALUATION OF DIFFERENT METHODS FOR DETERMINATION OF CHOLESTEROL IN SOME ANIMAL FOOD SOURCES
}

\author{
Eman Sh. M. Laz and Nehad A. Bardrawy \\ Animal Health Research Institute
}

\begin{abstract}
A comparison was carried out between a simple method of High performance Liquid Chromatography (HPLC), Gas Chromatography $(G C)$, enzymatic and colorimetric methods for determination of cholesterol levels. Linearity, accuracy, precision and detection limits were evaluated for HPLC and the other analytical methods. The results revealed that the HPLC method recorded the best linearity (correlation coefficient, $r=0.99992)$, followed by the GC $(r=$ $0.99874)$, the enzymatic $(r=0.99469)$ and the colorimetric method $(r$ $=0.99316)$. The accuracy of the obtained data were calculated based on recovery of the cholesterol added to butter at three concentrations, (75, 150 and $225 \mathrm{mg} / \mathrm{l00g}$ ). At the low concentration $(75 \mathrm{mg} / 100 \mathrm{~g})$, the best recovery was estimated by HPLC. In contrast, the GC and the enzymatic methods showed greater recovery at the other two concentrations when compared with HPLC. However, the recovery which has been obtained by colorimetric method was above the limit, for the three concentrations. The precision results showed no significant differences when the cholesterol was determined within 4 days by HPLC, GC and colorimetric methods. However, when it was determined by the enzymatic method the precision results recorded significant differences within 2 days. The HPLC method was very sensitive to low concentration of cholesterol (detection limit $24 \mu / \mu L$ ) followed by the GC (detection limit $49 \mu / \mu L$ ), the colorimetric (detection limit $9 \mu \mathrm{g} / \mu \mathrm{L}$ ) and the enzymatic method (detection limit 11 $\mu \mathrm{g} / \mu \mathrm{L})$. The HPLC method has been successfully applied for quantitative assay of cholesterol in a variety of animal food sources.
\end{abstract}

Key words: Cholesterol, HPLC, GC, colorimetric, enzymatic, animal sources. 


\section{INTRODUCTION}

Cholesterol is currently the top nutrition concerns of consumers, it is sterol constituent found in animal products. The quantitative determination of cholesterol content in food has become increasing important for three major reasons. The first is health directly associated with the role of excess plasma cholesterol on heart and artery-related disease (Kannel et al, 1971; Brown, 1990; Abd El-Gawad et al., 2005). The second reason deals with the nutritional labeling of foods which is obligatory due to legal regulations in many countries. The third reason concern about the scientific research files. In order to comply with these regulations and, further, to facilitate nutritional planning for low cholesterol diets, accurate and precise methodology for cholesterol determination in various food products is imperative. Therefore, many studies were focused on a determination of cholesterol in food by using several methods. For example, with gas chromatography by capillary column with derivatization (Park and Addis 1985b; Park and Addis 1986 and 1986 b; King, et al., 1998; Hwang, et al., 2003 and Apprich and Ulberth, 2004) and without derivatization (Jiang, et al., 1991; Frega et al., 1992; Wu, et al., 1997; and Fletouris, et al., 1998), by enzymatic method assessed using enzymatic kits (Corlson and Goldfabr, 1977; Luhman, et al., 1990; Jiang, et al., 1991 and Rodriguez-Sureda, and Peinado-Onsurbe, 2005). As well as, the coloremetric method has been used also (Abell et al., 1952; and Bachman, et al. 1976). However, determination of cholesterol by liquid chromatography was estimated previously in food (Newkirk, and Sheppard, 1981; Sion and Boucher, 2001; Baggio et al., 2005). Though, numerous studies have focused on the determination of cholesterol by HPLC compared with the other determination method. Therefore, this study was aimed to determine quantitatively cholesterol in some animal food sources using a simple method of HPLC compared with GC, enzymatic and colorimetric methods. 


\section{MATERIALS AND METHODS}

\section{Samples:}

Liver, brain and butter of cattle origin, chicken egg and tallow (sheep tail fat) were bought from local market.

\section{Chemicals and reagents:}

All chemicals and solvents were of analytical grade; cholesterol standard was obtained from Fluka, (Steiheim, Switzerland). HPLC-grade methanol, acetonitryle and Isopropanol were purchased from SigmaAldrich. $O$-phthaladehyde were provided by Merck (Darmstadt, Germany).

\section{Analytical methods:}

\subsection{Sample preparation:}

Five grams of homogenized test samples were taken from liver, brain, butter, egg yolk and tallow. Butylated hydroxytoluene (BHT) $(0.011 \%$, w/w) was added as an antioxidant. The samples were saponified directly with methanolic potassium hydroxide $2 \mathrm{M}$ for $18 \mathrm{~h}$ at room temperature. The non-saponifiable matter was extracted with diethyl ether for two to three times. The upper layer was collected using separating funnel. The ether fraction was washed with distilled water to remove water soluble contaminant, the ether fraction passed through anhydrous sodium sulphate, (Baggio and Bragagnolo, 2002). Finally, the organic solvent layer was evaporated under nitrogen flush. The dried matter was re-dissolved in a mobile phase of HPLC (methanol/ acetonitrile/isopropanol, 75:5:20 v/v/v) then, injected into HPLC and $\mathrm{GC}$, and the same extract was used to assay cholesterol by enzymatic and colorimetric methods. 


\subsection{Preparation of standard curve:}

The cholesterol standard curves were prepared from stock solution ( $0.1 \mathrm{mg}$ of cholesterol in $1 \mathrm{ml}$ of HPLC mobile phase). Working solutions were prepared by appropriately diluting aliquots from the stock with HPLC mobile phase to obtain solutions in the range of 0.1 to $6 \mu \mathrm{g} / 10 \mu \mathrm{L}$ for HPLC and GC, while, 10 to $60 \mu \mathrm{g} / 10 \mu \mathrm{L}$ for enzymatic and colorimetric methods.

\subsection{Accuracy:}

The accuracy of different methods was tested based on recovery of the cholesterol added to butter at three concentrations. One $\mathrm{mL}$ containing $7.5,15$ or $22.5 \mathrm{mg}$ of standard cholesterol was added to $10 \mathrm{~g}$ of butter then extracted by the method as described above to determine the content of cholesterol. Experiments without addition of cholesterol were used as control.

\subsection{HPLC analysis:}

Hewlett Packaged HPLC (Sereis 1050, HP, USA) was used, equipped with a quaternary pump solvent delivery system (Agilent 1100 , USA), autosampling injector (HP Sereis 1050), solvent degasser (HP Sereis 1050) and ultra-violet detector. The sample was injected into the Hypersil ODS C18 column (250 mm x $4.0 \mathrm{~mm}$. ID $5 \mu \mathrm{m}$ particle size). (Agilent, USA). The operating parameters were set as follows: column temperature, $35^{\circ} \mathrm{C}$; flow rate $1.0 \mathrm{ml} / \mathrm{min}$; UV-detector, $213 \mathrm{~nm}$. The isocratic elution was with methanol/acetonitryl/isopropanol (75:5:20 $\mathrm{v} / \mathrm{v} / \mathrm{v}$ ) as a mobile phase. Cholesterol was quantified by comparison of peak areas with those of standard curve. 


\subsection{GC analysis:}

Hewlett Packaged gas chromatography, model 5890 series II, equipped with a flame ionization detector (FID) was used. The determination of cholesterol was carried out according to the method of Apprich and Ulberth (2004) with slight modification as follows: The chromatograph was fitted with a HP-1 (crosslinked methyl silicone gum) $300 \mathrm{~m} \times 0.53 \mu \mathrm{m}$ capillary column, film thickness $0.88 \mu \mathrm{m}$. The oven temperature program was as follows: the initial temperature $170^{\circ} \mathrm{C}$ held for $2 \mathrm{~min}$, then heated to $300^{\circ} \mathrm{C}$ using a rate of $10^{\circ} \mathrm{C} / \mathrm{min}$, held for $5 \mathrm{~min}$. The detector temperature was set to $310^{\circ} \mathrm{C}$ and the injector temperature was set to $290^{\circ} \mathrm{C}$. Nitrogen was used as the carrier gas. Injections $1 \mu \mathrm{L}$ were carried out in the split ratio 10:1. The quantity of cholesterol was determined according to the peak areas with those of standard curve.

\subsection{Determination of detection limit:}

The detection limit of cholesterol by GC and HPLC using diluted cholesterol standard when the peak/noise > 3. However, for enzymatic and colorimetric methods, the detection limit recorded when the absorbance was 0.2 absorbance unite.

\subsection{Enzymatic assay:}

The cholesterol extract was transferred into test tube and dried under nitrogen flush, one $\mathrm{mL}$ of enzymatic kit reagent (Sentinel $\mathrm{Ch}$. Milan, Italy) was added, vortex gently, then determine in computerized spectrophotometer (Beckman IU 4500 USA) at $500 \mathrm{~nm}$. The standard curve was used to obtain the cholesterol concentration according to the method of Rodriguez-Sureda and Peinado-Onsurbe (2005). 


\subsection{Colorimetric analysis:}

The determination of cholesterol by colorimetric method as described by Bachman et al., (1976) was applied. The cholesterol extract was transferred into test tube, the solvent was evaporated under nitrogen flush, $4 \mathrm{ml}$ of $O$-phthaladehyde reagent was added (prepared fresh daily from dissolve $50 \mathrm{mg}$ in $100 \mathrm{ml}$ glacial acetic acid) and mixes thoroughly to dissolve sample. Wait $10 \mathrm{~min}$ and carefully add $2 \mathrm{ml}$ of concentrated $\mathrm{H}_{2} \mathrm{SO}_{4}$, mix tube immediately, wait 10-90 min and read absorbance at $550 \mathrm{~nm}$ (computerized spectrophotometer, Beckman IU 4500 USA) against reagent blank. The standard curve was used to obtain concentration of cholesterol in sample.

\section{Statistical analysis:}

Data obtained from the determination of cholesterol by different methods are presented as means and standard deviation. The least significant difference (LSD) at $p<0.05$ was applied to examine the differences among the cholesterol analytical methods and determination of cholesterol between days using general linear model procedure of Statistical Analysis Systems (SAS), (1990).

\section{RESULTS AND DISCUSSION}

\section{Linearity:}

Data in Table (1) showed coefficient of regression of cholesterol calibration standard curve of HPLC and other analytical methods. All of the method gave a good linear response and a correlation coefficient $(r)$ of $>0.993$ was observed between the concentration of the cholesterol standard and peak area (for HPLC and GC) or the absorbance (for enzymatic and colorimetric method). Regression equation analysis was computed and showed the response for all tested methods of calibration to be linear in the range examined $\left(\mathrm{y}_{1}=0.0053 x-0.296\right.$, for HPLC) $\left(\mathrm{y}_{2}=\right.$

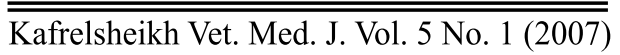


$0.0018 x+0.1332$ for $\mathrm{GC})\left(\mathrm{y}_{3}=64.457 x-1.6397\right.$ for enzymatic) $\left(\mathrm{y}_{4}=\right.$ $67.011 x-2.1091$ for colorimetric) where: $y_{1}$ and $y_{2}$ represent the peak of cholesterol for HPLC and GC, respectively. However, $\mathrm{y}_{3}$ and $\mathrm{y}_{4}$ represent the absorbance for enzymatic and colorimetric methods, respectively, and $x$ represents the quantity in $\mu \mathrm{g}$ of cholesterol on the volume of analysis. The results reveled that, the HPLC method recorded a best linearity $(r=0.99992)$ compared with other method followed by GC $(r=0.99874)$, enzymatic $(r=0.99469)$ and colorimetric method ( $r=$ 0.99316). Fletouris et al., (1998) found that the correlation coefficient was $r=0.99967$ for GC determination of cholesterol. Using HPLC method, Sion and Boucher, (2001) and Mestre Prates et al., (2006) reported $r=0.998$ and 0.9989 , respectively.

\section{Accuracy:}

To estimate the accuracy of the method, we performed a recovery experiment. Thus, three different concentrations of cholesterol standard (75, 150 and $225 \mathrm{mg} / 100 \mathrm{~g}$ ) were added to butter sample and the cholesterol were determined before and after addition. The results indicated that, all of our applied methods gave a good recovery. At the low concentration $(75 \mathrm{mg} / 100 \mathrm{~g})$, the finest recovery was estimated by HPLC (100). In contrast, the GC and enzymatic methods observed the greatest recovery at the other two concentrations when compared with HPLC. However, the recovery which has been obtained from colorimetric method gave higher limits, at the three concentrations. In general enzymatic method gave a slightly higher overall recovery (98.02\%) than HPLC and GC methods (97.66 and 96.49\%, respectively) The enzymatic method give a lower RSD\% (0.39\%) than other methods, HPLC, GC and colorimetric (2.63, 2.26 and 0.96, respectively). Comparing the cholesterol added and arithmetic results by the method of HPLC, GC and enzymatic (Table 1), it was found that the cholesterol 
arithmetic almost equal or lower than cholesterol added, these findings reveled that, no interference was present in the extracted sample. On the other side, cholesterol arithmetic by colorimetric method was higher than its added (Table 1), these findings may be caused by the interference accurred. Sion and Boucher, (2001) reported that the recovery of determination of cholesterol added in the extract at $0.62 \mu \mathrm{mol} / \mathrm{ml}$ by HPLC was $100 \pm 4 \%$. At concentration 500 and $1000 \mu \mathrm{g}$ cholesterol added to soybean oil, Hwang et al., (2003) found 96.4 and $90.7 \%$ recovery respectively by HPLC. In parallel, Mastere Prates et al., (2006) found $93 \%$ of the cholesterol average recovery by HPLC at three concentrations 0.03, 0.3 and $3 \mathrm{mg}$. Fletouris et al., (1998) found that the recovery of GC method for cholesterol added to Regato cheese at 60, 120 and $180 \mathrm{mg} / 100 \mathrm{~g}$ was 98, 97.75 and $98.67 \%$, respectively. King et al., (1998) observed that the GC recoveries of cholesterol added at $1 \mathrm{mg} / \mathrm{ml}$ were $74 \%$ for underivatized sample and $90.3 \%$ for the derivatized. Piironen et al., (2002) reported that the recovery of cholesterol which determined by GC was $94.9 \pm 4.3 \%$ when added to meat and meat products at level of $0.5 \mathrm{mg} / 10 \mathrm{~g}$.

\section{Precision:}

The precision of the HPLC and other analytical methods was studied by assaying three samples of liver on each of 4 days (Table 3 ). Variance estimates within day of cholesterol determined by HPLC gave least variance (RSD\% 1.83) compared with other analytical methods (RSD\% 5.68, 1.52 and 2.52 for GC, enzymatic and colorimetric, respectively). The statistical analysis revealed no significant differences between days when determined the cholesterol by HPLC, GC and colorimetric methods. However, when it was determined by enzymatic method the precision results recorded a significant differences between days. 


\section{Detection limit:}

Table (4) showed the detection limit of HPLC and other analytical methods. The HPLC method is very sensitive to low concentration of cholesterol (detection limit $24 \mathrm{ng} / \mu \mathrm{L}$ ) followed by GC (detection limit 49 $\mu \mathrm{g} / \mu \mathrm{L}$ ), colorimetric (detection limit $9 \mu \mathrm{g} / \mu \mathrm{L}$ ) and enzymatic (detection limit $11 \mu \mathrm{g} / \mu \mathrm{L})$.

\section{Applications:}

Quantititave determination of cholesterol in some animal food sources like liver, brain, butter, egg yolk and tallow (sheep tail fat) by HPLC compared with GC, enzymatic and colorimetric methods was given in Table 5. The cholesterol content in brain varied from 1156.43 to $1373 \mathrm{mg} / 100 \mathrm{~g}$ depends on the determination method. HPLC recorded a lower RSD \% (0.23\%) compared with other methods followed by GC (3.17\%), enzymatic $(4.42 \%)$ and colorimetric $(9.01 \%)$. Determination of cholesterol in brain gave no significant difference between all methods except enzymatic method which gave a significant difference. For cholesterol in liver, higher significant values have been found by colorimetric and enzymatic than HPLC and GC methods. In contrast, GC method exhibited a lower significant value compared with other methods, but the method of HPLC gave a moderate value, lower than colorimetric and enzymatic and higher than GC method. The cholesterol content in tallow and butter determined by colorimetric method revealed a higher significant results compared with other methods, in parallel, egg yolk cholesterol content analyzed by enzymatic method. In general, colorimetric method gave a higher value of cholesterol compared with $\overline{\bar{K} \text { Kafrelsheikh Vet. Med. J. Vol. } 5 \text { No. } 1 \text { (2007) }}$ 
HPLC and GC for all samples (significant in liver, tallow, egg yolk and butter and non significant in brain). These results confirmed by Jiang et al., (1991), whom reported that the cholesterol content in egg yplk determined by colorimetric method gave a higher significant value than by the enzymatic, GC and HPLC methods. These results also agree with Sion and Boucher, (2001) whom reported that, the cholesterol determined by HPLC generally lower than that obtained by colorimetric or enzymatic methods and also decided that, such methods are not specific and they fail to measure separate cholesterol and desmosterol. However, the amounts of cholesterol are in the range of values reported by other authors using different methods (Table 6). Nevertheless, we observed variations between the different studies. In conclusion the determination of cholesterol by HPLC method with direct saponification, is very good and suitable for estimation of cholesterol because it gives best linearity, accuracy and precision, moreover it is highly sensitive to detect the low concentration of cholesterol with short retention time.

Table (1): Coefficient of regression of cholesterol calibration standard curve of HPLC and other analytical methods.

\begin{tabular}{||l||c||c||c||}
\hline & Intercept & Slope & Correlation coefficient (r) \\
\hline \hline HPLC & -0.296 & 0.0053 & 0.99992 \\
\hline GC & +0.1332 & 0.0018 & 0.99892 \\
\hline Enzymatic & -1.6397 & 64.457 & 0.99469 \\
\hline Colorimetric & -2.1091 & 67.011 & 0.99316 \\
\hline
\end{tabular}

$\overline{\text { Kafrelsheikh Vet. Med. J. Vol. } 5 \text { No. } 1 \text { (2007) }}$ 
Eman Sh. M. Laz \& Nehad A. Bardrawy

Table (2): Accuracy of HPLC compared with other methods depends on recovery of the cholesterol added to butter at three concentrations.

\begin{tabular}{|c|c|c|c|c|}
\hline Method & $\begin{array}{c}\text { Cholesterol } \\
\text { added mg/100g }\end{array}$ & $\begin{array}{l}\text { Cholesterol } \\
\text { found }\end{array}$ & $\begin{array}{l}\text { Cholesterol } \\
\text { arithmetic* }\end{array}$ & Recovery \% \\
\hline HPLC & $\begin{array}{c}0 \\
75 \\
150 \\
225\end{array}$ & $\begin{array}{l}225.30 \\
300.71 \\
368.79 \\
443.01\end{array}$ & $\begin{array}{c}- \\
75.41 \\
143.49 \\
217.71\end{array}$ & $\begin{array}{c}100.55 \\
95.66 \\
96.98\end{array}$ \\
\hline $\begin{array}{l}\text { Over all recovery } \\
(\mathrm{RSD} \%)^{\Psi}\end{array}$ & & & & $97.66 \pm 2.57(2.63)$ \\
\hline GC & $\begin{array}{c}0 \\
75 \\
150 \\
225\end{array}$ & $\begin{array}{l}217.09 \\
287.60 \\
363.10 \\
437.86\end{array}$ & $\begin{array}{c}- \\
70.51 \\
145.01 \\
220.77\end{array}$ & $\begin{array}{l}94.01 \\
97.34 \\
98.12\end{array}$ \\
\hline $\begin{array}{l}\text { Over all recovery } \\
(\mathrm{RSD} \%)\end{array}$ & & & & $96.49 \pm 2.18(2.26)$ \\
\hline Enzymatic & $\begin{array}{c}0 \\
75 \\
150 \\
225\end{array}$ & $\begin{array}{l}256.23 \\
329.44 \\
403.76 \\
476.96\end{array}$ & $\begin{array}{c}- \\
73.21 \\
147.53 \\
220.73\end{array}$ & $\begin{array}{l}97.60 \\
98.35 \\
98.10\end{array}$ \\
\hline $\begin{array}{l}\text { Over all recovery } \\
(\mathrm{RSD} \%)\end{array}$ & & & & $98.02 \pm 0.38(0.39)$ \\
\hline Colorimetric & $\begin{array}{c}0 \\
75 \\
150 \\
225\end{array}$ & $\begin{array}{l}230.85 \\
307.60 \\
386.76 \\
460.66\end{array}$ & $\begin{array}{c}- \\
76.75 \\
155.91 \\
229.81\end{array}$ & $\begin{array}{l}102.33 \\
103.94 \\
102.14\end{array}$ \\
\hline $\begin{array}{l}\text { Over all recovery } \\
(\mathrm{RSD} \%)\end{array}$ & & & & $102.80 \pm 0.99(0.96)$ \\
\hline
\end{tabular}

* Calculated by (cholesterol found after adding - before adding).

${ }^{\Psi}$ Relative standard division.

$\overline{\overline{\text { Kafrelsheikh Vet. Med. J. Vol. } 5 \text { No. } 1 \text { (2007) }}}$ 
Table (3): Precision data based on the determination of cholesterol in liver by HPLC compared with GC, Enzymatic and Colorimetric methods.

\begin{tabular}{|c|c|c|c|}
\hline Method & Day & $\begin{array}{l}\text { Cholesterol mg/100g } \\
\qquad(\text { mean } \pm \mathrm{SD})\end{array}$ & $\mathrm{RSD} * \%$ \\
\hline \multirow{4}{*}{ Variance estimates within day } & 1 & $613.85 \pm 9.90^{\mathrm{a}}$ & 1.6 \\
\hline & 2 & $614.50 \pm 7.70^{\mathrm{a}}$ & 1.25 \\
\hline & 3 & $620.65 \pm 6.78^{\mathrm{a}}$ & 1.1 \\
\hline & 4 & $617.59 \pm 9.38^{a}$ & 1.52 \\
\hline \multirow{4}{*}{ Variance estimates within day } & 1 & $558.08 \pm 10.83^{\mathrm{a}}$ & 1.94 \\
\hline & 2 & $556.45 \pm 25.02^{\mathrm{a}}$ & 4.49 \\
\hline & 3 & $538.80 \pm 17.46^{\mathrm{a}}$ & 3.24 \\
\hline & 4 & $535.36 \pm 30.39^{\mathrm{a}}$ & 5.68 \\
\hline \multirow{4}{*}{$\begin{array}{c}\text { Enzymatic } \\
\text { Variance estimates within day }\end{array}$} & 1 & $681.99 \pm 1.9^{\mathrm{ab}}$ & 0.28 \\
\hline & 2 & $659.82 \pm 9.05^{\mathrm{b}}$ & 1.37 \\
\hline & 3 & $682.88 \pm 17.93^{\mathrm{a}}$ & 2.63 \\
\hline & 4 & $690.12 \pm 12.47^{\mathrm{a}}$ & 1.83 \\
\hline \multirow{4}{*}{$\begin{array}{c}\text { Colorimetric } \\
\text { Variance estimates within day }\end{array}$} & 1 & $685.59 \pm 14.15^{\mathrm{a}}$ & 2.06 \\
\hline & 2 & $686.40 \pm 18.19^{\mathrm{a}}$ & 2.65 \\
\hline & 3 & $678.61 \pm 24.09^{\mathrm{a}}$ & 3.55 \\
\hline & 4 & $690.11 \pm 12.47^{\mathrm{a}}$ & 1.81 \\
\hline
\end{tabular}

Note: Means and standard deviation of three samples analyzed in triplicate. Values in the same column bearing the differ letter are significantly different $(\mathrm{p}<0.05)$.

* Relative standard deviation.

$\overline{\overline{\text { Kafrelsheikh Vet. Med. J. Vol. } 5 \text { No. } 1 \text { (2007) }}}$ 
Eman Sh. M. Laz \& Nehad A. Bardrawy

Table (4): Detection limits of cholesterol using HPLC GC, Enzymatic and Colorimetric methods.

\begin{tabular}{|c||c|c||c||c|}
\hline \multirow{2}{*}{ Methods } & HPLC & GC & Enzymatic & Coloremetric \\
& $\mu \mathrm{g} / \boldsymbol{\mu L}$ & $\mu \mathrm{g} / \boldsymbol{\mu L}$ & $\boldsymbol{\mu g} / \boldsymbol{\mu L}$ & $\boldsymbol{\mu g} / \boldsymbol{\mu L}$ \\
\hline \hline Detection limit & 24 & 49 & 9 & 11 \\
\hline
\end{tabular}
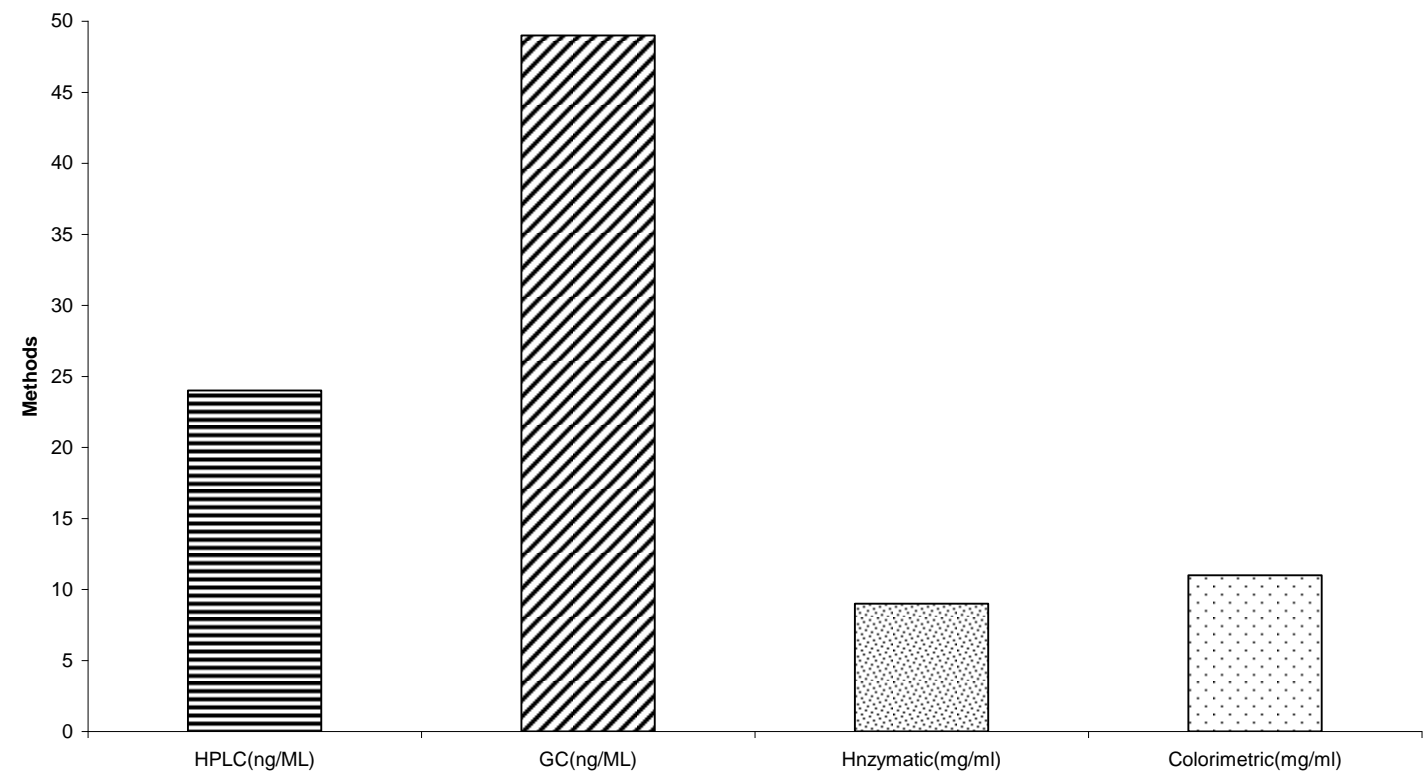

Detection Limit of chelesterol using HPLC, GC, Enzymatic and Coloremetric 
Table (5): Cholesterol content $(\mathrm{mg} / 100 \mathrm{~g})$ in some different food animal sources products determined by HPLC compared with GC, Enzymatic and Colorimetric methods.

\begin{tabular}{|c|c|c|c|c|c|c|c|c|}
\hline ||Product|| & HPLC & $\begin{array}{c}\text { RSD* } \\
\%\end{array}$ & GC & $\mid \begin{array}{c}\text { RSD } \\
\%\end{array}$ & Enzymatic & $\begin{array}{c}\text { RSD } \\
\%\end{array}$ & Colorimetric & $\begin{array}{c}\text { RSD } \\
\%\end{array}$ \\
\hline Brain & $\begin{array}{r}1403.11 \\
\pm 3.23^{\mathrm{a}}\end{array}$ & 0.23 & $\begin{array}{l}1373.60 \\
\pm 43.51^{\mathrm{a}}\end{array}$ & 3.17 & $\begin{array}{l}1156.43 \\
\pm 51.10^{\mathrm{b}}\end{array}$ & 4.42 & $\begin{array}{c}1426.21 \\
\pm 128.44^{\mathrm{a}}\end{array}$ & 9.01 \\
\hline Liver & $\begin{array}{l}613.85 \\
\pm 9.90^{\mathrm{b}}\end{array}$ & 1.61 & $\begin{array}{r}558.08 \\
\pm 18.75^{\mathrm{c}}\end{array}$ & $\mid$\begin{tabular}{||c|c}
3.36 \\
$\mid$
\end{tabular} & $\begin{array}{r}681.99 \\
\pm 1.93^{\mathrm{a}}\end{array}$ & $\mid 0.28$ & $\begin{array}{r}685.59 \\
\pm 14.15^{\mathrm{a}}\end{array}$ & $\mid 2.06$ \\
\hline Tallow & $\begin{array}{r}65.80 \\
\pm 2.60^{\mathrm{b}}\end{array}$ & 3.95 & $\begin{array}{c}54.75 \\
\pm 2.77^{\mathrm{c}}\end{array}$ & $\mid$\begin{tabular}{||c|}
$\mid$ \\
5.06
\end{tabular} & $\begin{array}{r}57.67 \\
\pm 2.60^{c}\end{array}$ & $\mid 4.51$ & $\begin{array}{r}73.91 \\
\pm 1.87^{\mathrm{a}}\end{array}$ & 2.53 \\
\hline $\begin{array}{l}\text { Egg } \\
\text { yolk }\end{array}$ & $\begin{array}{r}1089.55 \\
\pm 7.86^{c}\end{array}$ & 0.72 & $\begin{array}{l}1086.86 \\
\pm 23.58^{\mathrm{c}}\end{array}$ & $\mid 2.17$ & $\begin{array}{l}1476.03 \\
\pm 37.85^{\mathrm{a}}\end{array}$ & $\mid 2.56$ & $\begin{array}{l}1327.36 \\
\pm 44.06^{\mathrm{b}}\end{array}$ & $\mid 3.32$ \\
\hline Butter & $\begin{array}{l}225.30 \\
\pm 0.25^{\mathrm{c}}\end{array}$ & 0.11 & $\begin{array}{l}217.09 \\
\pm 8.40^{\mathrm{c}}\end{array}$ & 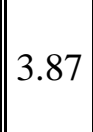 & $\begin{array}{r}256.23 \\
\pm 6.13^{\mathrm{b}}\end{array}$ & $\mid 2.39$ & $\begin{array}{r}277.51 \\
\pm 8.38^{\mathrm{a}}\end{array}$ & $\mid 3.02$ \\
\hline
\end{tabular}

Note: Means and standard deviation of three samples analyzed in triplicate. Values in the same row bearing the differ letter are significantly different $(\mathrm{p}<0.05)$

Relative standard deviation.

$\overline{\overline{\text { Kafrelsheikh Vet. Med. J. Vol. } 5 \text { No. } 1 \text { (2007) }}}$ 


\section{REFERENTES}

- Abd El-Gawad, I. A.; El-Sayed, E. M.; Hafez, S. A.; El-Zeini, H. M. and Saleh, F. A. (2005): The hypocholesterolaemic effect of milk yoghurt and soy-yoghurt containing bifidobacteriia in rats fed on a cholesterol-enriched diet. International Dairy Journal 15: 37-44.

- Abell, L. L.; Levy, B. B.; Brodie, B. B. and Kendall, F. E. (1952): A simplified method for the estimation of total cholesterol in serum. J. Bio. Chem. 195: 357-366.

- Apprich, S. and Ulberth, F. (2004): Gas chromatographic properties of common cholesterol and phytosterol oxidation products. Journal of Chromatography, 1055, 169-176.

- Bachman, K. C.; Jan-Hai Lin and Wilcox, C, J. (1976): Sensitive colorimetric determination of cholesterol in dairy products. Journal of the AOAC, 59: 5, 1146-1149.

- Baggio, S. R., and Bragagnolo, N. (2002): Chlosterol oxides, cholesterol, total lipid and fatty acid composition of turkey meat. Journal of Agricultural and Food Chemistry. 50: 59815986.

- Baggio, S. R.; Miguel, A, M. R. and Bragagnolo, N. (2005): Simultaneous determination of cholesterol oxides, cholesterol and fatty acids in processed turkey meat products. Food Chemistry 89: 475-484.

- Brown, W. V. (1990): Dietary recommendation to prevent coronary heart disease. Annals of New York Academy of Science, 598, 376-388.

- Corlson, S. E., and Goldfabr, S. (1977): A sensitive enzymatic $\overline{\bar{K} \text { Kafrelsheikh Vet. Med. J. Vol. } 5 \text { No. } 1 \text { (2007) }}$ 
method for the determination of free and esterified tissue cholesterol. Clinica Chimica Acta, 79: 575-582.

- Fletouris, D. J.; Botsoglou, N. A.; psomas, I. E. and Mantis, A. I. (1998): Rapid determination of cholesterol in milk and milk products by direct saponification and capillary gas chromatography. Journal of Dairy Science 81: 2833-2840.

- Frega, N., Bocci, F., and Lercker, G. (1992): Direct gas chromatographic analysis of the unsaponifiable fraction of different oils with a polar Capillary column. JAOCS, 69, 447450.

- Hwang, B-S.; Wang, J-T. and Choong, Y-M. (2003): Asimplified method for the quantification of total cholesterol in lipids

using gas chromatography. Journal of Food Composition and Analysis, 16, 169-178.

- Jiang, Z.; Fenton, M.; and Sim, J. S. (1991): Comparison of four different methods for Egg cholesterol determination. Poultry Science 70: 1015-1019.

- Kannel, W. B., Castell, W. P., Gordon, T., and McNamara, P. M. (1971): Serum cholesterol in lipoprotein and the risk of coronary heart disease. Annals of International Medicine, 74, 112.

- King, A. J.; Paniangvait, P.; Jones, A. D. and German, J. B. (1998): Rapid method for quantification of cholesterol in Turky meat and products. $63,3: 382-385$.

- Luhman, C. M.; Miller, B. G. and Beitz, D. C. (1990): Research Note: The effect of feeding lovastatation and colestipol on production and cholesterol content of eggs.

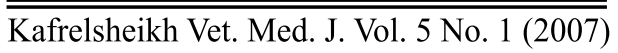


Poultry Science 69: 852-855.

- Mestre Prates, J. A.; Goncalves Quaresma, M. G.; Branquinho Bessa, R. J.; Andrade Fontes, Carlos, M. G. and Mateus Alfaia, C. M. P. (2006): Simultaneous HPLC quantification of total cholesterol, tocopherols and $\beta$-carotene in Barrosa-PDO veal. Food Chemistry 94: 469-477.

- Newkirk, D. R. and Sheppard, A. J. (1981): High pressure liquid chromatography determination of cholesterol in food. Journal of the Association of Official Chemists, 64: 54-57.

- Park, S. W. and Addis, P. B. (1985b): Capillary column gas liquid chromatography resolution of oxidized cholesterol derivatives. Anal. Biochem. 149:275-283.

- Park, S. W. and Addis, P. B. (1986a): Identification and quantitative estimation of oxidized cholesterol derivatives in heated tallow. J. Agric. Food Chem. 34:653-659.

- Park, S. W. and Addis, P. B. (1986b): Further investigation of oxidized cholesterol derivatives in heated fats. J. Food Sci. 51: 1380-1381.

- Piironen, V; Toivo, J and Lampi, A. M. (2002): New data for cholesterol contents in meat, fish, milk, eggs and their products consumed in Finland J. Food Composition and Analysis. 15: 705-713.

- Rodriguez-Sureda, V. and Peinado-Onsurbe, J. (2005): A procedure for measuring triacylglyceride and cholesterol content using a small amount of tissue. Analytical Biochemistry 343: 277-282.

- SAS (1990): Statistical Analysis Systems. User Guide Statistics, Version 6.0 Inst., Inc., Cary, NC. 
- Sion, B. and Boucher, D. (2001): Quantitative analysis of desmosterol, cholesterol and cholesterol sulfate in semen by high-performance liquid chromatography. Journal of Chromatography 935: 259-265.

- Wu, W. H., Lillard, D. A., and Akoh, C. C. (1997): Direct saponification: a simple and rapid method for determination of total cholesterol and fatty acid composition of aquatic foods. Journal of Food and Lipids, 4: 97-107.

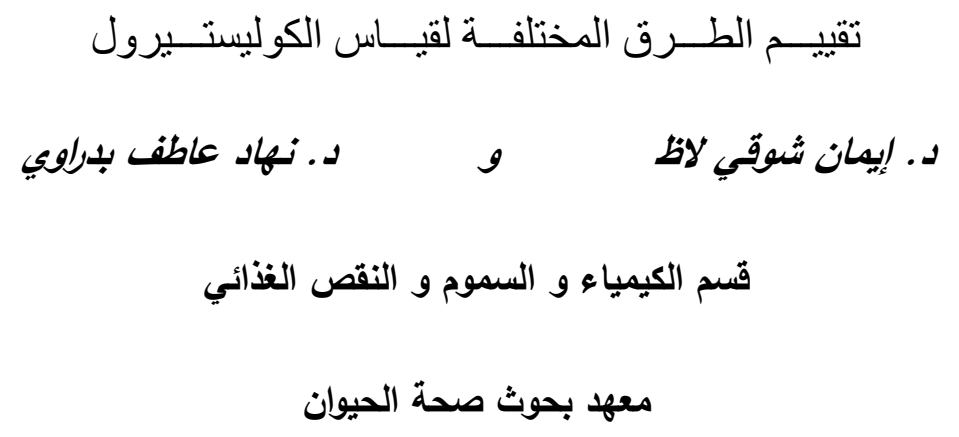

أجريت مقارنـة بين عدة طرق تستخدم لقياس مستوى الكوليستيرول حيث تم القياس باستخدام السـائل الكرومـاتوجرافي عـالي الأداء (HPLC) والكرومـاتوجراف الغـازي (GC) والتحليـل الانزيمسي والتحليل الطيفي. تم تقديم خطية وضبط دقة وحدود وجود الكولستيرول باستخدام (HPLC) والطرق التحليلية الأخرى. وقد أوضحت النتائج أن أحسن خطية كانت باستخدام (HPLC) يليها المكرماتجراف العازي (GC) تم التحليل الإنزيمي وفي النهاية التحليل الطيفي. وقد تم حساب دقة النتائج على أساس استعادة الكوليستيرول المضاف إلى الزبد في ثلاث تركيزات مختلفة (75، 150، 225 ملجم/100جم). وقد سجلت النتائج أحسن استعادة بالنسبة لأقل تركيز (75ملجم/100جم) باستخدام (HPLC) وعلى 
العكس كـان أعلى استعادة للتركيزاين الأخريين باسـتخدام (GC) والتحليـل الإنزيمسي عند مقارنتها

باستخدام (HPLC). بينما كانت الاستعادة المسجلة باستخدام طريقة التحليل الطيفي أعلى من الحد للتركيزات الثلاثة. وقد أوضحت نتائج الدقة عدم وجود خلايا معنوية عند قياس مستوى الكوليستيرول في خلال أربعة أيام باستخدام (HPLC)، (GC) والتحليل الطيفي، بينما سجلت نتائج الدقة خلايا معنوية باستخدام التحليل الإنزيمي. 